\title{
Coir-Krishimithra: An Apposite Medium for Cultivation of Vegetable/ Medicinal/ Ornamental Plants
}

\author{
Radhakrishnan $\mathrm{S}^{1}$, Anita Das Ravindranath ${ }^{2}$, Abesh Reghuvaran ${ }^{3}$, Geena $\mathrm{MG}^{4}$
}

\begin{abstract}
Coir pith is a by-product of the coir fibre processing industry. Accumulation of coir pith leads to an environmental concern and its management is a major problem with all coir industrialists. Therefore biodegradation of coir pith is an essential requirement to control pollution. Coir pith is a potential wealth and can be converted into valuable organic manure by microbial degradation. A method of composting of coir pith with urea has been developed by Coir Board which uses a fungus viz., Pithplus (Pleurotus sajor caju). Application of urea releases higher concentration of ammonia in the soil making it more acidic and retards soil natural fertility. Hence an alternative cost effective nitrogen supplement needs to be developed as a substitute to urea for composting of coir pith. Coir pith can be converted to effective organic manure with the use of fungus (Pleurotus sajor caju) along with the addition of nitrogen supplements like Azolla, Neem cake and Fish waste in 1:1:1 proportion. The present study aims at the formulation of bioorganic manure from coir pith avoiding urea in the composting. Overall assessment on the physico chemical properties of the biodegraded coir pith leads to the conclusion that a combination of Azolla, Neem cake and Fish waste in 1:1:1 proportion was found to be efficient in lignin degradation and contribute to novel changes in coir pith. A study was conducted to evaluate the competence of biocompost thus produced for the cultivation of Amaranthus and Groundnut. Studies confirmed that Coir-KrishiMithra can be used as an effective growing media and hence, the use of Coir-KrishiMithra, a 100\% organic manure can be entertained in homes, nurseries and fields for the cultivation of plants mainly vegetables; thereby promoting the eco-friendly organic cultivation and minimize the environmental pollution caused by chemical fertilizers.
\end{abstract}

Key words: Coir pith, organic manure, composting

\footnotetext{
${ }^{1}$ Senior Scientific Officer (i/c), Department of Microbiology, Central Coir Research Institute (Coir Board), Alleppey, Kerala, India. Email: rkharipad@gmail.com

${ }^{2}$ Director, Central Coir Research Institute (Coir Board), Alleppey, Kerala, India.

Email: anitadas30@gmail.com

${ }^{3}$ Project Associate, Department of Microbiology, Central Coir Research Institute (Coir Board), Alleppey, Kerala, India. Email: abesh199@gmail.com

${ }^{4}$ Project Associate, Department of Microbiology, Central Coir Research Institute (Coir Board), Alleppey, Kerala, India. Email: geenamg@gmail.com
} 


\section{Introduction}

Coir pith, which is also known as coir dust is the main byproduct in coir extraction industries. In the husk, coconut fibres are seen tightly packed along with non-fibrous, fluffy and light weight corky material known as coir pith or coir dust, which constitutes about 50-70 percent of the husk. The spongy material that binds the coir fibre in the husk is the coir waste or coir pith. The composition and properties of coir pith vary depending on maturity of coconut, method of extraction and disposal, period between extraction and use and environmental factors. Normally coir pith is dumped as agricultural waste and accumulates as heaps of coarse and fine dust. Coir pith is a recalcitrant agro-residue containing high amount of lignin and cellulose resisting decomposition by microorganisms under natural conditions. The recalcitrant nature of coir pith is due to the presence of lignin. It contains $8-12 \%$ soluble tannin like phenolics. Coir pith has high water holding capacity of 8 times of its weight. Nutrient content of coir pith varies with place, method of retting, rate of decomposition and storage method.

Lignin constitutes the second most abundant group of biopolymers in Biosphere. Cellulosic compounds present in coir waste supports the initial growth of fungus and acts as co-substrate for lignin degradation (Higuchi. T, 1980). Coir wastes after biodegradation can be effectively used as manure for increasing the yield of crops (Ramaswamy, 1986). Coir pith used as potting medium showed a spectacular increase of water holding capacity when tomato plants were grown on coir pith based potting mixture (Baskaran, M \& Saravanan, A., 1997). Microorganisms produce extracellular enzymes (ligninase and cellulases) to degrade lignocelluloses in plant biomass (Akhmodeva, 1992). Degradation of coir pith can be effectively done with suitable species of Bacideomycetes fungus (Pleurotus sajor caju) in combination with nitrogen fixing bacteria (Mandare VK etal, 2003). Bio composting process is available means of converting various organic waste generated from the industry and the agricultural sectors into beneficial products such as biofertilizer and as a soil conditioner. The unique features of this agricultural waste are their organic content, $\mathrm{pH}$, and high $\mathrm{C}$ : $\mathrm{N}$ ratio. A process of composting has been standardized by Central Coir Research Institute (Coir Board) for preparation of organic manure / fertilizer out of coir pith using urea as nitrogen supplement The manure thus obtained is rich in nitrogen $(1.26 \%)$, phosphorous $(0.06 \%)$ and potassium $(1.20 \%)$ which is essential for plant growth. An exclusively novel method for accelerating the composting of coir pith hillock was also developed at CCRI (Ghosh et al., 2007). Through this technology, the composting of coir pith could be achieved within 21 days and the compost thus produced showed an increased percentage of nitrogen (1.24\%), phosphorous $(0.055 \%)$ and potassium $(1.16 \%)$ with reduced C: $\mathrm{N}$ ratio of $20: 1, \mathrm{pH}$ of about 6.8 and Electrical Conductivity of 0.23 millimhos $/ \mathrm{cm}$ making the compost as a desirable organic manure. The principal change brought about in coir pith during composting is the breakdown of lignin which forms the chief constituent (30\%) in it.

Although composting alleviates the problem of pollution by the accumulation of coir pith, urea which is being used as nitrogen source has some disadvantages. Application of urea for composting of coir pith exerts higher concentration of ammonia in the soil making it even acidic and retards soil natural fertility. High concentration of urea shows burn potential that will kill the plant roots. To overcome these disadvantages, an alternative cost effective nitrogen supplement has been developed using a combination of nitrogen supplements like Azolla, Neem cake and Fish waste in 1:1:1 proportion. A study was conducted to evaluate the competence of biocompost thus produced viz "Coir Krishimithra" for the cultivation of Amaranthus and Groundnut as a substitute for urea for composting of coir pith.

Amaranthus, collectively known as amaranth, is a cosmopolitan genus of annual or short-lived perennial plants. Some amaranth species are cultivated as leaf vegetables, pseudo cereals and ornamental plants. Most of the Amaranthus species are summer annual weeds and are commonly referred to as pigweed. Catkinlike cymes of densely packed flowers grow in summer or autumn. Approximately 60 species are 
recognized, with inflorescences and foliage ranging from purple, through red and green to gold. Members of this genus share many characteristics and uses with members of the closely related genus Celosia. Amaranthus shows a wide variety of morphological diversity among and even within certain species. Although the family (Amaranthaceae) is distinctive, the genus has few distinguishing characters among the 70 species included. This complicates taxonomy and Amaranthus has generally been considered among systematists as a "difficult" genus.

The peanut, also known as groundnut which is taxonomically classified as Arachis hypogaea, is a legume crop grown mainly for its edible seeds. It is widely grown in the tropics and subtropics, being important to both small and large commercial producers. It is classified as both a grain legume and, because of its high oil content, as an oil crop. A typically among crop plants, peanut pods develop underground rather than aboveground. It is this characteristic that the botanist Linnaeus used to assign the specific name hypogaea, which means "under the earth". As a legume, peanuts harbor symbiotic nitrogenfixing bacteria in root nodules. This capacity to fix nitrogen means peanuts require less nitrogencontaining fertilizer and improve soil fertility, making them valuable in crop rotations. Peanuts are similar in taste and nutritional profile to tree nuts such as walnuts and almonds.

The present study aims to develop Coir KrishiMithra by composting coir pith using Pleurotus sajor caju along with the addition of nitrogen supplements viz. Azolla, Fish Waste and Neem cake and use the same for the cultivation of vegetable plants.

\section{Materials and Methods}

\section{Experimental Section}

Coir pith was collected from Kalavoor, Alappuzha district. Pleurotus sajor caju (PithPlus) was obtained from Microbiology Division, Central Coir Research Institute. Azolla and Neem cake were procured from Nurseries and fish waste was collected from Alappuzha fish market. Experimental protocol, biochemical analysis and field level studies of coir pith were carried out at CCRI, Kalavoor.

Azolla is a floating fern and belongs to the family of Azollaceae. Azolla hosts symbiotic blue green algae, Anabaena azollae, which is responsible for the fixation and assimilation of atmospheric nitrogen.On a dry weight basis; it contains 25-35 percent protein, 10-15 percent minerals and 7-10 percent of amino acids, bioactive substances and bio-polymers. Its nutrient composition makes it a highly efficient and effective feed for livestock. Nitrogen content: $5.8 \%$.

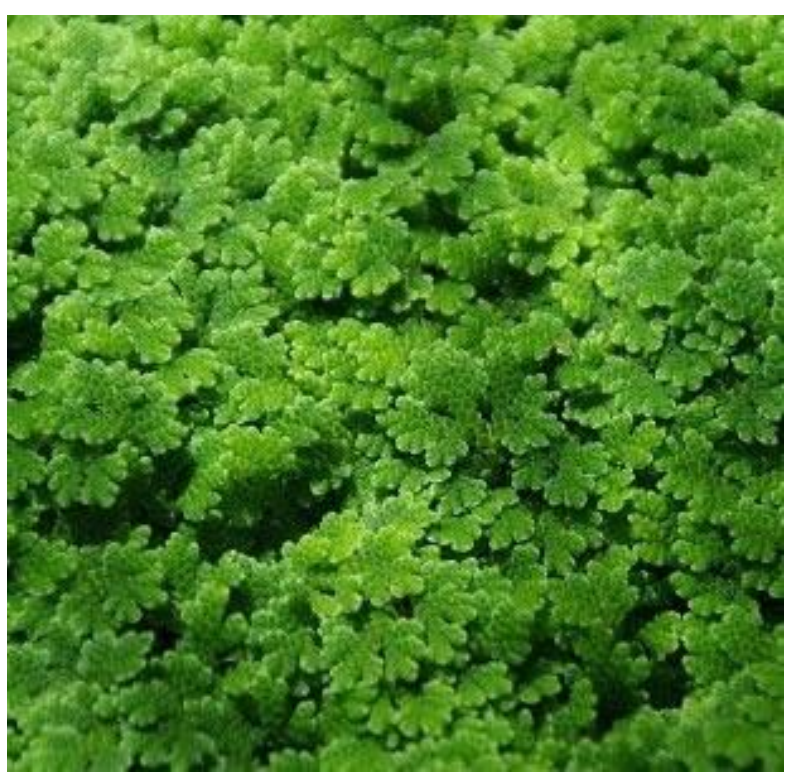

Fig Azolla

Fish waste- The fish processing industry is a major exporter of seafood and marine products in many countries. About $70 \%$ of the fish is processed before final sale. Processing of fish generates significant amount of waste (20-40\%) depending upon the level of processing and type of fish. Majority of the fish wastes are disposed off in the ocean, which in turn is polluting the aquatic environment. Fish waste generally contains $50-60 \%$ proteins, $10-20 \%$ fat and minerals. Nitrogen content: 9.8\%, Phosphorous$1.17 \%$, Potassium $-1.45 \%$. 


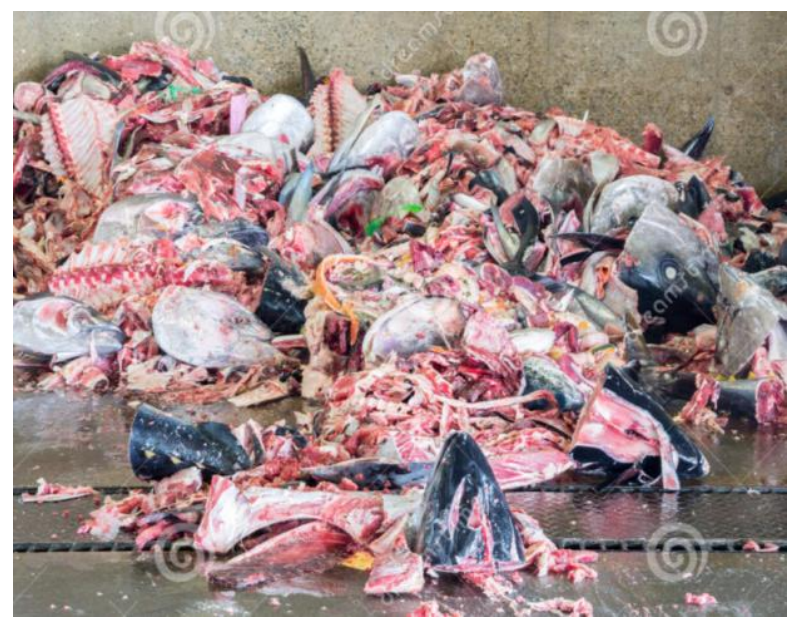

Fig Fish waste

Neem cake - Neem cake is the by-product obtained in the process of cold pressing of neem tree fruits and the solvent extraction process for neem oil cake. Neem has demonstrated considerable potential as a fertilizer. Neem cake has an adequate quantity of NPK in organic form for plant growth. Being a totally botanical product it contains essential micro nutrients as $\mathrm{Ca}, \mathrm{Mg}, \mathrm{S}$, $\mathrm{Zn}, \mathrm{Cu}, \mathrm{Fe}, \mathrm{Mn}$ etc. Nitrogen content: $7.6 \%$.

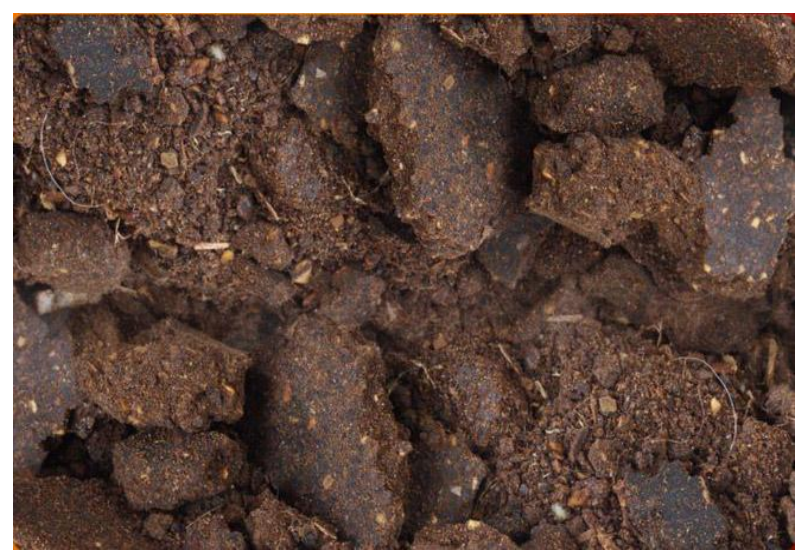

Fig Neem cake powder

\section{Composting Process}

Two lots of coir pith (1 ton each) in duplicate were laid as separate heaps. Pleurotus sajor caju spawn $(2 \mathrm{~kg})$ and urea $(5 \mathrm{~kg})$ was thoroughly mixed with the first lot of coir pith and Pleurotus sajor caju and nitrogen supplements viz. Azolla, Neem cake and fish waste with the second lot. Moisture content was maintained in both the lots and study was continued for 45 days and samples were drawn at periodic intervals.

\section{Field Experiment}

The coir pith compost prepared by using Pleurotus sajor caju and nitrogen supplements were compared with control (Garden soil) to check for its effectiveness in cultivation of vegetable plants.

\section{Analysis of chemical parameters: Composted Coir pith and Soil}

Analysis of lignin was carried out by Modified Klason Lignin assay, Nitrogen by Kjeldahl method, Organic carbon by Walkey and Black method, Phosphorous by spectrophotometer and Potassium by Flame photometer.

\section{Result and Discussion}

The results obtained on evaluation of Lignin content, Organic carbon and NPK of garden soil and Coir Krishimithra before and after decomposition with $P$. sajor caju are as shown in Table I. Lignin content of raw coir pith is 30\% which was reduced to $4.8 \%$ after biodegradation with P. sajor caju. Pleurotus spp. is known to decompose and utilize various agricultural wastes (Vijaya et al., 2008). From the results obtained, an increase in nitrogen content and a proportionate decrease in carbon were observed in the composted coir pith as reported in earlier work (Christopher et al., 2007).

Application of Azolla as nitrogen source to coir pith resulted in an enhancement of nitrogen to $0.86 \%$, phosphorous to $0.03 \%$ and potassium to $1.01 \%$. Addition of fish waste, another natural supplement exhibited comparatively reduced values of NPK viz $1.19 \%, 0.043 \%$ and $1.18 \%$ respectively. Neem cake, the third supplement resulted the highest value of $1.21 \%, 0.051 \%$ and $1.18 \%$ for NPK. Of the different combination trials on coir pith conducted, incorporation of Azolla, Fish waste and Neem cake powder (1:1:1) was observed to enhance the NPK in biodegraded pith. The addition of Azolla, Fish waste and Neem cake powder (1:1:1) has exhibited a maximum nitrogen content of $1.92 \%$ compared to the control of $0.26 \%$ in raw coir pith in a period 


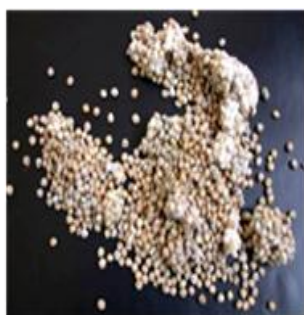

Pitlplus

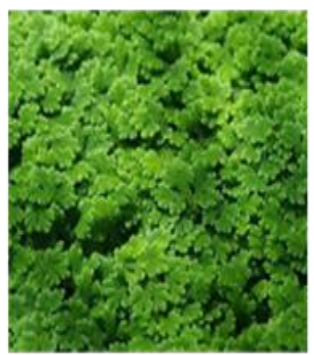

Azolla

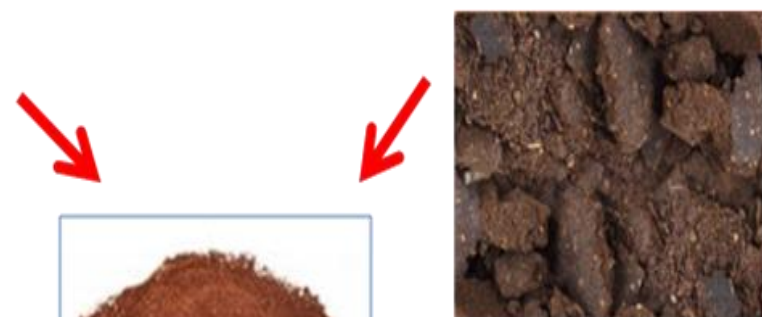

Neem Cake

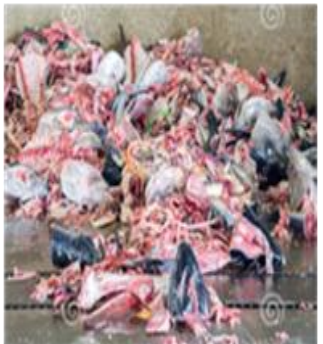

Fish Waste

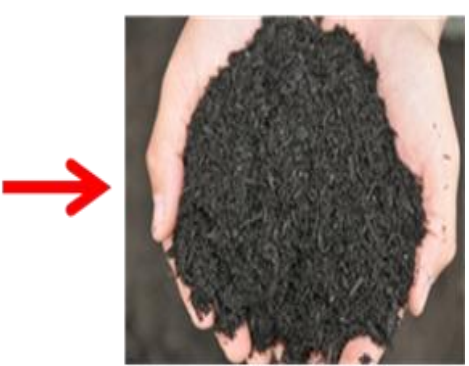

KRISHIMITHRA

\begin{tabular}{|c|l|c|c|c|c|c|}
\hline SI No & \multicolumn{1}{|c|}{ Parameters } & C-POM & $\begin{array}{c}\text { Azolla } \\
\text { alone }\end{array}$ & $\begin{array}{c}\text { Fish } \\
\text { waste } \\
\text { alone }\end{array}$ & $\begin{array}{c}\text { Neem cake } \\
\text { alone }\end{array}$ & Combination (1:1:1) \\
\hline 1 & Nitrogen (\%) & 1.26 & 0.86 & 1.19 & 1.21 & $\mathbf{1 . 9 2}$ \\
\hline 2 & Phosphorous (\%) & 0.06 & 0.03 & 0.043 & 0.051 & $\mathbf{0 . 4 1}$ \\
\hline 3 & Potassium (\%) & 1.20 & 1.01 & 1.18 & 1.18 & $\mathbf{1 . 9}$ \\
\hline 4 & Lignin (\%) & 4.8 & 11.2 & 8.7 & 8.2 & $\mathbf{4 . 8}$ \\
\hline 5 & Organic Carbon (\%) & 24.9 & 27.3 & 26.1 & 25.8 & $\mathbf{2 6 . 9}$ \\
\hline 6 & C:N Ratio & 19.76 & 32.1 & 22.1 & 21.1 & $\mathbf{1 4 . 1}$ \\
\hline 6 & pH & 6.8 & 6.5 & 6.6 & 6.8 & $\mathbf{6 . 9}$ \\
\hline
\end{tabular}

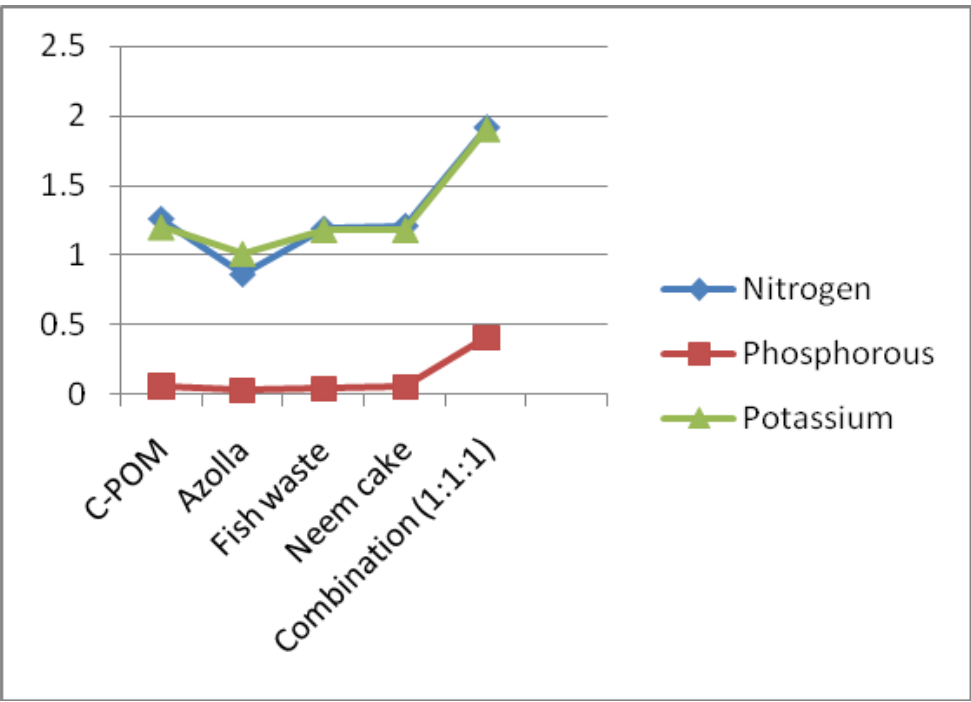


of 30 days. The same dosage of Urea, an inorganic chemical nitrogen fertilizer used in composting exhibited an increase of $1.26 \%$ of nitrogen in coir pith. Other essential elements needed for the growth of plants viz., phosphorous and potassium were also observed to be $0.41 \%$ and $1.9 \%$ in Coir Krishimithra, the composted coir pith.

A significant finding from the foregoing studies reveals that coir pith compost prepared by the addition of urea resulted in yielding $1.26 \%$ of nitrogen, $0.06 \%$ of phosphorous and $1.20 \%$ of potassium whereas the new combination of biological sources resulted in enrichment in NPK level to $1.19 \%, 0.043 \%$ and $1.18 \%$ respectively (Fig 3 ). Urea, the artificial fertilizer could be substituted by addition of Azolla, Fish waste and Neem cake powder $(1: 1: 1)$ and the technology is ecofriendly and cost effective. Hence the new combination of biological sources viz Azolla, Fish waste and Neem cake powder $(1: 1: 1)$ formulated in the present study is significant.

An important finding from the foregoing studies reveals the fact that composting of coir pith supplemented by combinations of biological sources viz Azolla, Fish waste and Neem cake powder $(1: 1: 1)$ result in a steep decrease in lignin content $(4.8 \%)$ from the control value of $30 \%$ (Fig 4). Addition of Azolla, Fish waste and Neem cake powder separately on coir pith resulted in decreased lignin content of $11.2 \%$, $8.7 \%$ and $8.2 \%$ as compared to the control value of $30 \%$ which substantiate the findings of Shashirekha and Rajarethinam (2007) of 42\% volume reduction in coir pith during composting. This could also be related to the findings of Garcia et al. (1980) who reported that white rot fungi are known to have evolved complex enzymatic machinery to degrade lignin, produce extracellullar polyphenols oxidases particularly Lignin peroxidase (LiP), Manganese peroxidase (MnP) and laccases, which are highly effective in depolymerisation of lignin in coir pith.

The present study also confirms the earlier findings of Moorthy (1981) who stated that the $\mathrm{pH}$ remained high until the end of composting process possibly (30 days) due to progressive utilization of organic substrates and increase in the mineral constituents of waste. The raw coir pith with a $\mathrm{pH}$ value of 5.4 shows an increase during composting and raises a neutral value of 6.9 in Coir Krishimithra, the composted coir pith. Investigation also reveals that incorporation of Azolla, Fish waste and Neem cake powder $(1: 1: 1)$ resulted in lowering of EC to 0.19 millimhos/cm in biodegraded coir pith compared to the control value of 1.3 millimhos $/ \mathrm{cm}$. The high conductivity indicated in raw coir pith could be attributed to the presence of polyphenols and tannins, which could be reduced by composting with Pleurotus sajor caju. Experimental results also showed a decreasing trend in salinity during composting to a tolerable limit of 0-1 ppt from 4 ppt as in raw coir pith by frequent sprinkling of water for maintenance of moisture on composting heaps.

Even though coir pith is enriched with micronutrients and possesses water retention properties which could be exploited for agricultural use, farmers hesitate using it mainly due to wider $\mathrm{C}$ : $\mathrm{N}$ ratio, presence of tannin related phenolic compounds and high lignin content (Kadalli and Suseela, 2002). Mandhare et al. (2003) reported that the C: $\mathrm{N}$ ratio of different agro-residues after cultivation of different Pleurotus sp shows significant reduction. Bisaria et al. (1987) reported that loss in weight of substrate might be due to loss of carbon in the form of carbon dioxide by respiratory activity of $P$. sajor caju during its growth. Shetty and Moorthy (1981) reported that the optimum value of $\mathrm{C}$ : $\mathrm{N}$ ratio for plant growth should be below 30:1. Ghosh et al. (2007) suggested that the composted coir pith prepared by the conventional method using urea had exhibited a reduced carbon: nitrogen ( $\mathrm{C}: \mathrm{N}$ ratio) from the control value of 112:1 in raw coir pith. The values for carbon and nitrogen obtained from the present study for composting of coir pith with combination of Azolla, Fish waste and Neem cake powder (1:1:1) also result in reduced $\mathrm{C}: \mathrm{N}$ ratio of $14: 1$ which is in accordance with the earlier findings of Ghosh (Fig. 6). 


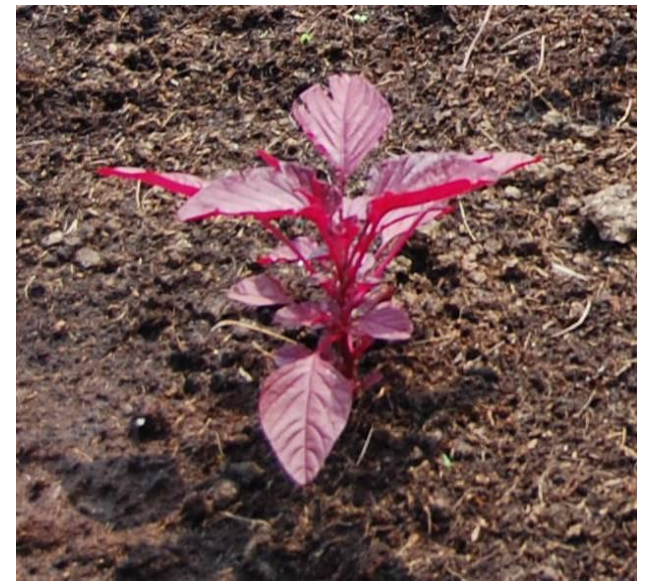

Figure I. Amaranthus Plant

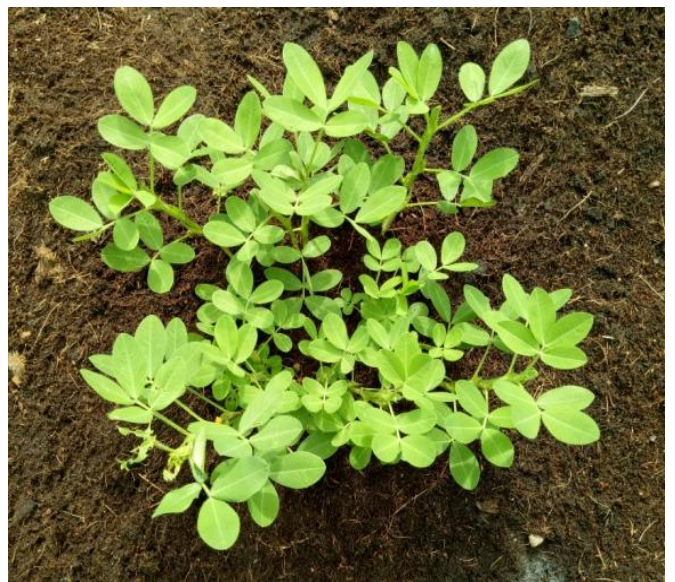

Figure II. Groundnut Plant

Table I. Lignin, OC and NPK content of Garden soil and Coir KrishiMithra

\begin{tabular}{|c|l|l|c|c|c|c|c|c|c|c|c|}
\hline \multirow{2}{*}{ SI No } & Cultivating media & \multicolumn{2}{|c|}{ Lignin (\%) } & \multicolumn{2}{|c|}{$\begin{array}{c}\text { Organic } \\
\text { Carbon } \\
(\%)\end{array}$} & \multicolumn{2}{|c|}{$\begin{array}{c}\text { Nitrogen } \\
(\%)\end{array}$} & \multicolumn{2}{|c|}{$\begin{array}{c}\text { Phosphorous } \\
(\%)\end{array}$} & \multicolumn{2}{|c|}{$\begin{array}{c}\text { Potassium } \\
(\%)\end{array}$} \\
\cline { 3 - 12 } & & $\begin{array}{c}0 \\
\text { days }\end{array}$ & $\begin{array}{c}45 \\
\text { days }\end{array}$ & $\begin{array}{c}0 \\
\text { days }\end{array}$ & $\begin{array}{c}45 \\
\text { days }\end{array}$ & $\begin{array}{c}0 \\
\text { days }\end{array}$ & $\begin{array}{c}45 \\
\text { days }\end{array}$ & $\begin{array}{c}0 \\
\text { days }\end{array}$ & $\begin{array}{c}45 \\
\text { days }\end{array}$ & $\begin{array}{c}0 \\
\text { days }\end{array}$ & $\begin{array}{c}45 \\
\text { days }\end{array}$ \\
\hline 1 & Garden Soil & \multicolumn{2}{|c|}{-} & \multicolumn{2}{|c|}{20} & \multicolumn{2}{|c|}{4.12} & \multicolumn{2}{|c|}{0.56} & \multicolumn{2}{|c|}{0.79} \\
\hline 2 & Coir KrishiMithra & 30 & 17 & 29 & 24 & 0.26 & 4.14 & 0.05 & 0.47 & 0.67 & 1.92 \\
\hline
\end{tabular}

Table II. Leaf number, shoot and root length of plants

\begin{tabular}{|c|c|c|c|c|c|c|c|c|c|c|c|c|c|c|c|c|c|c|c|}
\hline \multirow{3}{*}{$\begin{array}{l}\text { Sl } \\
\text { No }\end{array}$} & \multirow{3}{*}{ Plant Name } & \multicolumn{6}{|c|}{ Leaf number } & \multicolumn{6}{|c|}{ Shoot length $(\mathrm{cms})$} & \multicolumn{6}{|c|}{ Root length (cms) } \\
\hline & & \multicolumn{3}{|c|}{$\begin{array}{c}\text { Garden } \\
\text { Soil }\end{array}$} & \multicolumn{3}{|c|}{ KrishiMithra } & \multicolumn{3}{|c|}{$\begin{array}{c}\text { Garden } \\
\text { Soil }\end{array}$} & \multicolumn{3}{|c|}{ KrishiMithra } & \multicolumn{3}{|c|}{$\begin{array}{c}\text { Garden } \\
\text { Soil }\end{array}$} & \multicolumn{3}{|c|}{ KrishiMithra } \\
\hline & & 0 & 30 & 45 & 0 & 30 & 45 & 0 & 30 & 45 & 0 & 30 & 45 & 0 & 30 & 45 & 0 & 30 & 45 \\
\hline 1 & $\begin{array}{l}\text { Amaranthus } \\
\text { cruentas }\end{array}$ & 0 & 20 & 36 & 0 & 25 & 40 & 0 & 12 & 28 & 0 & 16 & 32 & 0 & 0 & 14 & 0 & 0 & 19 \\
\hline 2 & $\begin{array}{l}\text { Arachis } \\
\text { hypogaea }\end{array}$ & 0 & 22 & 35 & 0 & 22 & 35 & 0 & 15 & 20 & 0 & 16 & 24 & 0 & 0 & 16 & 0 & 0 & 18 \\
\hline
\end{tabular}


Table III. Plant Height, number of branches and width of leaves of plants

\begin{tabular}{|c|c|c|c|c|c|c|}
\hline \multirow{2}{*}{$\begin{array}{c}\text { Cultivating } \\
\text { Media }\end{array}$} & \multicolumn{2}{|c|}{$\begin{array}{c}\text { Plant height at harvest } \\
\text { (cm) }\end{array}$} & \multicolumn{2}{c|}{$\begin{array}{c}\text { Number of branches / } \\
\text { plant at harvest }\end{array}$} & \multicolumn{2}{c|}{ Width of the leaf (cm) } \\
\cline { 2 - 7 } & $\begin{array}{l}\text { Amaranthus } \\
\text { cruentas }\end{array}$ & $\begin{array}{l}\text { Arachis } \\
\text { hypogaea }\end{array}$ & $\begin{array}{l}\text { Amaranthus } \\
\text { cruentas }\end{array}$ & $\begin{array}{l}\text { Arachis } \\
\text { hypogaea }\end{array}$ & $\begin{array}{l}\text { Amaranthus } \\
\text { cruentas }\end{array}$ & $\begin{array}{l}\text { Arachis } \\
\text { hypogaea }\end{array}$ \\
\hline Garden soil & 113 & 34 & 14 & 12 & 7.9 & 6.9 \\
\hline $\begin{array}{c}\text { Coir } \\
\text { KrishiMithra }\end{array}$ & 125 & 40 & 19 & 17 & 9.1 & 9.3 \\
\hline
\end{tabular}

\section{Growth Physiology}

The growth physiology observed on cultivation of the plants is as shown in Table II. The cultivation experiment was carried out to study the effect of coir pith based potting mixture with garden soil on Amaranthus and Groundnut plants. Maximum plant growth (leaf number, shoot length and root length), plant height at harvest, number of branches per plant at harvest etc were monitored in plants grown in soil and Coir KrishiMithra. For both the plants, the controls (soil) show no significant increase in root and shoot length. But in plants cultivated in Coir Krishi Mithra, a considerable increase in shoot and root length were observed. The potential use of Coir Pith Organic Manure as a growing media for medicinal plants has already been studied. (Reghuvaran A and Ravindranath $\mathrm{AD}, 2014)$, but the present study shows light on the efficiency of other kind of plants including vegetables. The physical parameters tested showed a spectacular increase in the water holding capacity of the potting mixture. From the results it is observed that the plants grown in coir pith compost are well grown with more lengthy shoots and more number of leaves. Plant height, number of leaves, width of leaves was also estimated and shown in Table III. All the paramaters showed positive results which favours the Coir KrishiMithra as an excellent potting media for the cultivation of Amaranthus and Groundnut. This would have confirmed that Coir KrishiMithra can be used as an effective potting media for different kinds of Medicinal and Vegetable plants. Figure I and Figure II represents Amaranthus and Groundnut plants cultivated using Coir-KrishiMithra.

\section{Conclusion}

CCRI had developed a formulation named Coir Pith Organic Manure (C-POM) for improving the soil fertility. Since there were some problems associated with the conventional C-POM, the main one being usage of urea, a new method has been developed for the composting of coir pith. In the new method developed, urea was replaced by biological supplements viz. Azolla, Neem cake and fish waste called as Coir KrishiMithra. They have got high nitrogen content and hence can be a prospective substitute for urea. The studies conducted for the cultivation of Amaranthus and Groundnut in this enriched media shows that Coir KrishiMithra can be effectively used as a growing media.

\section{Acknowledgement}

The authors would like to express their gratitude to Shri. C.P. Radhakrishnan Ex MP, Chairman, Coir Board for his keen interest and encouragement.

\section{References}

Akhmedova ZR (1992). Biodegradation of plant wastes by the fungus, Pleurotus ostreatus. Information of biologically valuable products. Soviet Biotech. 5; 95100.

Baskaran M and Saravanan A, (1997). Effect of coir pith based potting mix and methods of fertilizer application on tomato. Madras Agric J., 84; 476-480. 
Bisaria, R., Madan, M. and Bisaria, V.S. (1987) Mineral content of the mushroom $P$. sajor caju cultivated on different agro residues. Mush. J. Trop. 7: 53-60.

Christopher PA, Viswajith V, Prabha S, Sudhakar K and Mallika P. (2007), Effect of coir pith based cyanobacterial basal and foliar biofertilizer on Basella rubra L., Acta Agriculturae Slovenica. 89; 5963.

Garcia-Martinez, D.V., Shinmyo, Madia, A. and Deman, A. L. (1980) Studies on cellulose production by Clostridium thermocellum. Europ. J. Appl. Microbiol. Biotechnol. 9: 189-197.

Ghosh, P.K., Sarma, U.S., Ravindranath, A.D., Radhakrishnan, S. and Prasenjeet Ghosh (2007) A Novel Method for Accelerated Composting of Coir Pith. Energy Fuels. 21 (2).

Higuchi, T. (1980) Lignin Biodegradation: Microbiology, Chemistry and Potential Applications. Eds T.K. Kirk, T. Higuchi and Hou-Min Chang.CRC Press, Boca Raton, Florida, p.1.

Kadalli, G.G. and Suseela Devi, L. (2002) Evaluation of enriched coir dust compost for integrated nutrient management system. Dept of Soil Science and Agril. Chemistry, University of Agril. Sciences, GKVK, Bangalore.

Mandhare, V.K., Suryawanshi, A.A., Jadav, V.T. and Patil, H.B. (2003) Biochemical changes in different agrowastes due to cultivation of Pleurotus spp. Madras Agr.J; 289-291.
Ramaswamy K (1986) National Seminar on Integrated Nutrient Management in cropping system (TNAU, Madras. Jan 21$23,21$.

Reghuvaran A and Ravindranath AD (2014), Use of coir pith compost as an effective cultivating media for Ornamental. Medicinal and Vegetable plants. International Journal of Biology, Pharmacy and Allied Sciences (IJBPAS). 3(1); 88-97.

Shashirekha, M.N. and Rajarathinam, S. (2007) Bioconversion and biotransformation of coir pith for economic production of Pleurotus florida. Chemical and biochemical changes in coir pith during the mushroom growth and fructification World J. Microbiol Biotechnol. 23: $1107-$ 1114.

Shetty, K.S. and Moorthy, K.V. (1981) Possibility of protein enrichment of straw by mushroom $P$. sajor caju. In: Recycling (ed. M.S. Karla), Punjab Agri. Univ. Ludhiana, 63-67.

Vijaya D, Padmadevi SN, Vasandha S, Meerabhai RS and Chellapandi P (2008). Effect of vermi-composted coir pith on the growth of Andrographis paniculata, $J$. Org. Syst., 3; 51-56. 